\title{
Development of supernumerary premolars in the mandible after orthodontic extraction - A case report
}

\author{
Yongwen Guo ${ }^{1}$, Xueming Wang ${ }^{2}$ and Ding Bai ${ }^{1 *}$ \\ ${ }^{1}$ State Key Laboratory of Oral Diseases, Department of Orthodontics, West China Hospital of Stomatology, Sichuan University, Chengdu, China \\ ${ }^{2}$ Oral Department of People's Hospital of Xindu District, Chengdu, China
}

\begin{abstract}
Supernumerary premolars are relatively rare and the etiology of supernumerary tooth formation is complicated and has not yet been well known up to now. The present case documents a case of supernumerary premolars developing in the mandibular premolar region after extractions of the first premolars for orthodontic treatment in an Asian boy. What is special is that they positioned exactly where the extracted premolars used to be. Theoretical considerations for the development of them are postulated from the perspectives of tooth development and engineered tooth regeneration. Residual dental epithelial cells and mesenchyme cells in the alveolar fossas after orthodontic extraction of young permanent premolars may have the potential to proliferate, recombine and interact with each other leading to the development of supernumerary teeth under the inductive microenvironment of alveolar fossas.
\end{abstract}

\section{Introduction}

Supernumerary teeth may be defined as any teeth or tooth substance in excess of the usual configuration of twenty deciduous, and thirty-two permanent teeth [1]. They may occur in any region of the dental arch, either as isolated events or multiply, unilaterally or bilaterally, erupted or unerupted, in single or both arches, or as part of a syndrome or disease, or can be found in non-syndromic patients $[2,3]$. Supernumerary premolars are relatively rare and they constitute almost $10 \%$ of the total supernumerary cases, of which the prevalence reported in the literatures varies between $0.5 \%$ and $5.3 \%$ in the permanent dentition, and proximately $75 \%$ of those are in the mandible $[4,5]$. Yusof's review found that mandibular premolar region was the most common site of occurrence for non-syndrome associated supernumerary teeth [6]. There also has been reported that Asian populations or males have a higher frequency in occurrence of supernumerary teeth $[7,8]$. Besides, among supernumeraries, supernumerary premolars are found to be more commonly developed than estimated and are special in terms of their late development and recurrence, which make treatment plans variable and complicated [7]. Some of the theories for the presence of supernumerary teeth include atavism, division of the tooth germ, hyperactivity of the dental lamina, and genetic and environmental factors [9]. Although a number of possible theories have been postulated, the exact etiology for supernumerary teeth is still uncertain.

The present case documents another case of supernumerary premolars occurring in the mandible. What is special about this case is that the supernumerary premolars were developed after the orthodontic extraction of the first premolars, and they positioned exactly at the places where the extracted premolars used to be.

\section{Case report}

The patient, an Asian boy, initially presented for orthodontic treatment with a chief complaint of irregular teeth and protrusion at age 12. Intraoral examination showed permanent dentition with severe crowding in upper arch and moderate in lower arch. Routine panoramic and lateral radiographs were taken. The panoramic showed all permanent teeth present including the third molars. At this time, there was no radiographic evidence of supernumerary teeth developing (Figure 1).

For orthodontic treatment, four first premolars were extracted. At age 14, orthodontic treatment was completed with and subsequent panoramic and lateral radiographs were taken. It was noted that early crown developments of two supernumerary teeth were in the lower premolar regions, where exactly the extracted lower premolars used to be. The left one was more developed than the right one (Figure 2). The present two supernumerary premolars were surgically removed carefully under the guidance of cone beam computed tomography (CBCT) in case of future pathological changes and damage of adjacent teeth.

\section{Discussion}

As is well known, tooth development is a complex process that takes place through reciprocal interactions between the dental epithelium and the neural crest-derived dental ectomesenchyme that forms the dental papilla and dental follicle. Epithelial-mesenchymal interaction plays important roles in tooth genesis and development [10-12]. At the initial stage of tooth development, the epithelium produces the first instructional signals to the mesenchyme. The mesenchyme then responds signals back to the epithelium [13].

Correspondence to: Ding Bai, State Key Laboratory of Oral Diseases, Department of Orthodontics, West China Hospital of Stomatology, Sichuan University, No.14, 3rd Section, Renmin South Road, Chengdu, 610041, China, Tel: 86-02885501474, Fax: 86-028-85582167, E-mail: baiding@scu.edu.cn

Key words: supernumerary premolars, tooth development, dental stem cells, tooth regeneration

Received: May 23, 2017; Accepted: June 08, 2017; Published: June 11, 2017 


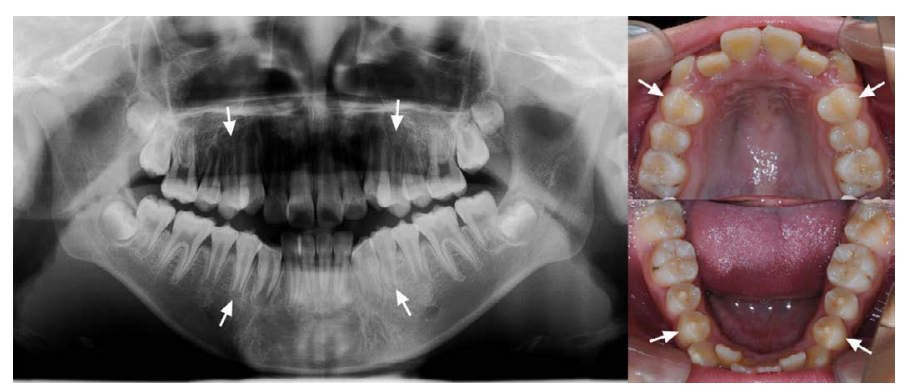

Figure 1. Pretreatment panoramic radiograph and intraoral photographs showed no evidence of supernumerary teeth developing in a 12-year old boy. Arrows indicated four premolars extracted for orthodontic treatment.

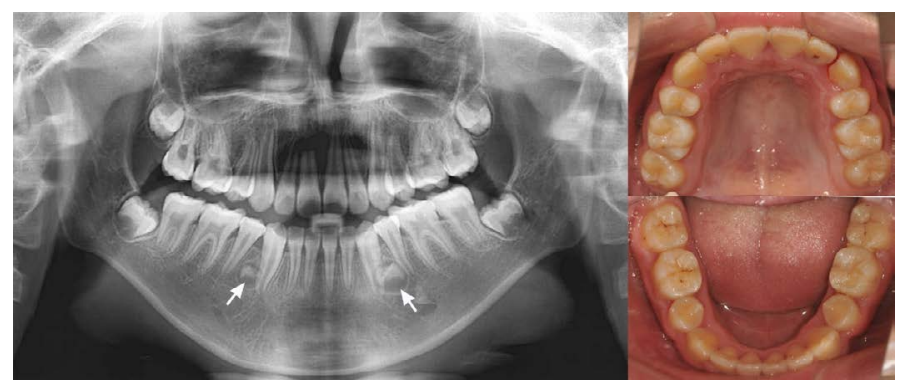

Figure 2. Posttreatment panoramic radiograph and intraoral photographs showed early crown developments of two supernumerary teeth in the lower premolar regions (Indicated by arrows). The left one was more developed than the right one.

Epithelial rests of Malassez cells (ERM), which are development residues of Hertwig's epithelial root sheath, are unique epithelial cells in the periodontal ligament. They remain in periodontal tissues throughout the adult life in cord or net-like formations or as isolated islands near the cementum [14]. It is generally acknowledged that their functional role is to maintain the homeostasis of the periodontium through reciprocal interactions with other periodontal cells [15]. In recent years, there are studies suggesting that ERM cells might contain stem cell characteristics $[16,17]$. The primary culture of ERM cells contains a population of primitive stem cells in which epithelial stem cell markers and embryonic stem cell markers were expressed [15]. Furthermore, there have been reports of epithelial stem cells in the periodontium might be involved in the formation of enamel-like structures. Tummers and Thesleff's study indicated that epithelial stem cells can give rise to both the ameloblast and root epithelium cell lineage which created distinct tooth patterns [18]. Another study also demonstrated that quiescent ERM can differentiate into ameloblastlike cells when subcultured and generate enamel-like tissues in combination with dental pulp cells at the crown formation stage when transplanted in vivo [19].

What's more, beginning in 2000, several human dental mesenchymal stem/progenitor cells have been isolated and characterized, including dental pulp stem cells (DPSC), stem cells from exfoliated deciduous teeth(SHED cells), stem cells from apical papilla (SCAP cells), periodontal ligament stem cells (PDLSCs), and dental follicle precursor, or progenitor cells (DFPCs) [20]. These mesenchymal stem cells can not only give rise to the other components of the tooth: dentin, pulp, cementum, and periodontal ligament, but also could differentiate into at least 3 distinct lineages [21,22].

In the case presented here, there is no familial history of supernumerary teeth. The development of the first premolars had not completed yet. It was expected that the ERM as well as the dental MSCs would be more prominent in teeth with incomplete root formation [23]. After orthodontic tooth extractions, there remained ERM and dental MSCs in the alveolar fossas, especially the PDLSCs, SCAP cells, DFPCs and DPSC (Figure 3). Dental cells are verified to have the capacity to reorganize themselves into a proper organ during the early stages of tooth development [24,25]. The classical tissue recombination experiments also indicated that either the dental epithelium or dental mesenchyme has the competence to direct tooth development depending on the stage of tooth morphogenesis [26,27]. In present case, the ERM were therefore supposed to act as an epithelial component proliferating, recombining and interacting with the dental MSCs after orthodontic extractions. Subsequently, tooth genesis and crown formation initiated under the inductive microenvironment of alveolar fossas. The ERM would differentiate into ameloblasts and give rise to enamel while the dental MSCs form the other components of the tooth. There is still an approximate $8 \%$ possibility of recurrence of supernumerary premolars even after surgical removals. Long term follow-up by taking radiographic surveys periodically is of great necessity.

Therefore, epithelial-mesenchyme recombination has been one of the strategies for bioengineered tooth regeneration in recent years [28-30]. However, tooth initiation is regulated by delicate activatorinhibitor mechanisms between the epithelial and mesenchymal cells [31]. Although researches in recent years have taught us much about the molecular mechanisms of tooth morphogenesis and differentiation [9], these intricate mechanisms underlying supernumerary tooth formation as well as the initiation of tooth formation are still unclear up to date. Consideration for the presence of supernumerary teeth in current case is theoretical based on previous studies and many questions are still doubtable and debatable. Experimental evidences are needed to illustrate these issues and more information about the molecular mechanisms of supernumerary teeth would better provide assistances in understanding of tooth genesis and development as well as engineered tooth regeneration.

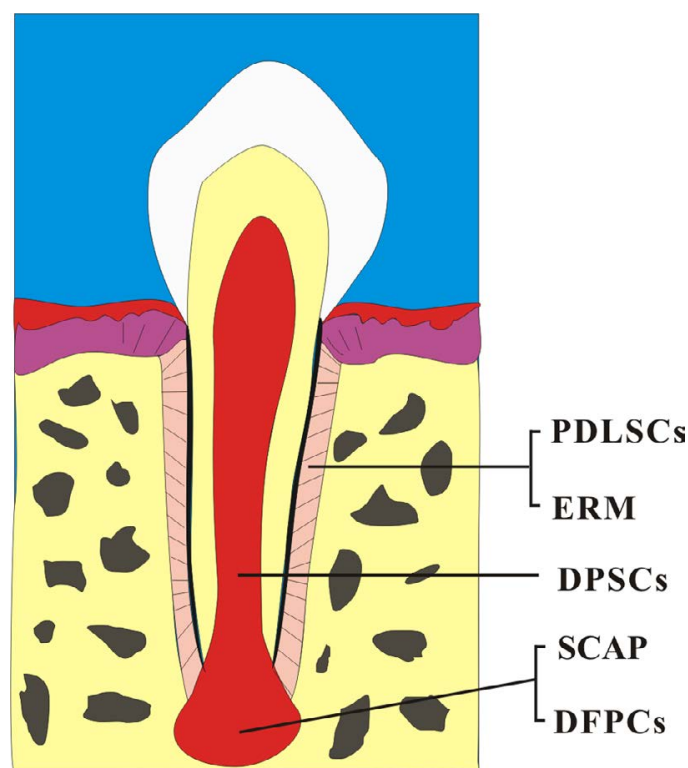

Figure 3. Residual dental stem/progenitor cells around or in the tooth may have the potential to proliferate, recombine and interact in the alveolar fossas after orthodontic extraction leading to the development of tooth. PDLSCs, periodontal ligament stem cells ERM, epithelial rests of Malassez cells; DPSCs, dental pulp stem cells; SCAP, stem cells from root apical papilla; DFPCs, dental follicle precursor, or progenitor cells. 


\section{References}

1. Leco Berrocal MI, Martín Morales JF, Martínez González JM (2007) An observational study of the frequency of supernumerary teeth in a population of 2000 patients. Med Oral Patol Oral Cir Bucal 12: E134-138. [Crossref]

2. Díaz A, Orozco J, Fonseca M (2009) Multiple hyperodontia: report of a case with 17 supernumerary teeth with non syndromic association. Med Oral Patol Oral Cir Bucal 14: E229-231. [Crossref]

3. Ferres-Padro E, Prats-Armengol J, Ferres-Amat E (2009) A descriptive study of 113 unerupted supernumerary teeth in 79 pediatric patients in Barcelona. Med Oral Patol Oral Cir Bucal 14: E146-152. [Crossref]

4. Hyun HK, Lee SJ, Ahn BD, Lee ZH, Heo MS, Seo BM et al. (2008) Nonsyndromic multiple mandibular supernumerary premolars. J Oral Maxillofac Surg 66: 1366-1369. [Crossref]

5. Kawashita Y, Saito T (2010) Nonsyndromic multiple mandibular supernumerary premolars: a case report. J Dent Child (Chic) 77: 99-101. [Crossref]

6. Yusof WZ (1990) Non-syndrome multiple supernumerary teeth: literature review. $J$ Can Dent Assoc 56: 147-149. [Crossref]

7. Solares R, Romero MI (2004) Supernumerary premolars: a literature review. Pediatr Dent 26: 450-458. [Crossref]

8. Zhu JF, Marcushamer M, King DL, Henry RJ (1996) Supernumerary and congenitally absent teeth: a literature review. J Clin Pediatr Dent 20: 87-95. [Crossref]

9. Wang XP, Fan J (2011) Molecular genetics of supernumerary tooth formation. Genesis 49: 261-277. [Crossref]

10. Thesleff I, Nieminen P (1996) Tooth morphogenesis and cell differentiation. Curr Opin Cell Biol 8: 844-850. [Crossref]

11. Jernvall J, Thesleff I (2000) Reiterative signalling and patterning during mammalian tooth morphogenesis. Mech Dev 92: 19-29. [Crossref]

12. Zhang YD, Chen Z, Song YQ, Liu C, Chen YP (2005) Making a tooth: growth factors, transcription factors, and stem cells. Cell Res 15: 301-316. [Crossref]

13. Thesleff I, Keranen S, Jernvall J (2001) Enamel knots as signaling centers linking tooth morphogenesis and odontoblast differentiation. Adv Dent Res 15: 14-18. [Crossref]

14. Peters BH, Peters JM, Kuhn C, Zoller J, Franke WW (1995) Maintenance of cell-typespecific cytoskeletal character in epithelial cells out of epithelial context: cytokeratins and other cytoskeletal proteins in the rests of Malassez of the periodontal ligament. Differentiation 59: 113-126. [Crossref]

15. Nam H, Kim J, Park J, Park JC, Kim JW, Seo BM, et al. (2011) Expression profile of the stem cell markers in human Hertwig's epithelial root sheath/Epithelial rests of Malassez cells. Mol Cells 31: 355-360. [Crossref]

16. Sonoyama W, Seo BM, Yamaza T, Shi S (2007) Human Hertwig's epithelial root sheath cells play crucial roles in cementum formation. J Dent Res 86: 594-599. [Crossref]
17. Foster BL, Popowics TE, Fong HK, Somerman MJ (2007) Advances in defining regulators of cementum development and periodontal regeneration. Curr Top Dev Biol 78: 47-126. [Crossref]

18. Tummers M, Thesleff I (2008) Observations on continuously growing roots of the sloth and the K14-Eda transgenic mice indicate that epithelial stem cells can give rise to both the ameloblast and root epithelium cell lineage creating distinct tooth patterns. Evol Dev 10: 187-195. [Crossref]

19. Shinmura Y, Tsuchiya S, Hata K, Honda MJ (2008) Quiescent epithelial cell rests of Malassez can differentiate into ameloblast-like cells. J Cell Physiol 217: 728-738. [Crossref]

20. Sedgley CM, Botero TM (2012) Dental stem cells and their sources. Dent Clin North Am 56: 549-561. [Crossref]

21. Shi S, Bartold PM, Miura M, Seo BM, Robey PG, et al. (2005) The efficacy of mesenchymal stem cells to regenerate and repair dental structures. Orthod Craniofac Res 8: 191-199. [Crossref]

22. Huang GT, Gronthos S, Shi S (2009) Mesenchymal stem cells derived from dental tissues vs. those from other sources: their biology and role in regenerative medicine. $J$ Dent Res 88: 792-806. [Crossref]

23. Becktor KB, Nolting D, Becktor JP, Kjaer I (2007) Immunohistochemical localization of epithelial rests of Malassez in human periodontal membrane. Eur J Orthod 29: 350353. [Crossref]

24. Duailibi MT, Duailibi SE, Young CS, Bartlett JD, Vacanti JP, et al. (2004) Bioengineered teeth from cultured rat tooth bud cells. J Dent Res 83: 523-528. [Crossref]

25. Ohazama A, Modino SA, Miletich I, Sharpe PT (2004) Stem-cell-based tissue engineering of murine teeth. J Dent Res 83: 518-522. [Crossref]

26. Kollar EJ, Baird GR (1970) Tissue interactions in embryonic mouse tooth germs. I. Reorganization of the dental epithelium during tooth-germ reconstruction. $J$ Embryol Exp Morphol 24: 159-171. [Crossref]

27. Lumsden AG (1988) Spatial organization of the epithelium and the role of neural crest cells in the initiation of the mammalian tooth germ. Development 103: 155-169. [Crossref]

28. Nakao K, Morita R, Saji Y, Ishida K, Tomita Y, et al. (2007) The development of a bioengineered organ germ method. Nat Methods 4: 227-230. [Crossref]

29. Angelova Volponi A, Kawasaki M, Sharpe PT (2013) Adult human gingival epithelia cells as a source for whole-tooth bioengineering. J Dent Res 92: 329-334. [Crossref]

30. Ikeda E, Morita R, Nakao K, Ishida K, Nakamura T, Takano-Yamamoto T, et al. (2009) Fully functional bioengineered tooth replacement as an organ replacement therapy. Proc Natl Acad Sci U S A 106: 13475-13480.

31. Kavanagh KD, Evans AR, Jernvall J (2007) Predicting evolutionary patterns of mammalian teeth from development. Nature 449: 427-432. [Crossref]

Copyright: $(2017$ Guo Y. This is an open-access article distributed under the terms of the Creative Commons Attribution License, which permits unrestricted use, distribution, and reproduction in any medium, provided the original author and source are credited. 